\title{
Design and Content Validity Analysis of Physics Test based on Local Wisdom for High School Students
}

\author{
Nunung Fadilah ${ }^{1}$, Mundilarto ${ }^{2}$
}

\section{ARTICLE INFO \\ Article History: \\ Received 04.03.2019 \\ Received in revised form \\ 20.06.2019 \\ Accepted \\ Available online 01.10.2019}

\begin{abstract}
This research was conducted to design the physics test instrument based on local wisdom "Gasing" used in measuring the cognitive skill of the 11th-grade senior high school students and to analyze the content validity. The question format of the test is two-tier multiple-choice. The first tier consists of 5 answer choices and the second tier consists of 5 choices of answer reasons. A methodological study was conducted to examine the content validity of the physics test instrument through a twostep process (design and judgment). The design stage was conducted through five-steps, including determining the objectives, selecting the appropriate item format, preparing the table of specifications, writing the test items, and editing the test items. At the expert's judgment stage was to analyze the content validity obtained from the assessment of six validators (3 lecturers and 3 physics teachers) using the Aiken's formula. Based on the results of the research showed that the highest content validity value was one and the content validity index of 32 items was above 0.78 . Thus, the physics test instrument based on local wisdom "Gasing" that developed was valid and feasible in terms of the validity of its contents.
\end{abstract}

(C) IJERE. All rights reserved

Keywords:

Physics test, local wisdom, cognitive skills, content validity.

\section{INTRODUCTION}

Today, the values of local wisdom are increasingly eroded by the times (Chartok, 2010). One effort made by some researchers to instill and strengthen the values of local wisdom is to apply it in physics learning activities in schools (Vlachopoulos \& Makri, 2017; Guney \& Seker, 2012; Suastra \& Yasmini, 2013; Musanna, 2011). In addition, learning of physics based on local wisdom also aims to increase the value of meaningfulness of physics learning to students (Guney \& Seker, 2012). The meaningfulness is obtained when the learning is had relevance to everyday life according to student residence area (Wagiran, 2011). Therefore, the local wisdom values in a region should be considered in designing the physics learning activities to realize meaningful physics learning.

Local wisdom can be understood as a local cultural value that can regulate the life of society wisely (Mungmachon, 2012). Implementation of education by raising local wisdom can stimulate the student's senses to apply science, especially physics into the culture owned by the environment where they live (Bowker \& Tearle, 2007). The local wisdom applied in the study of physics must have characteristics corresponding to the material of physics being taught (Suastra \& Yasmini, 2013). The suitability of these characteristics makes the goal of physics learning achievable.

The application of local wisdom in the study of physics has a diverse form of delivery. The form of delivery can be through games, simulations, fieldwork, and projects (Mungmachon, 2012). One form of learning that can create a fun learning atmosphere is through the game (Verpoorten, Westera, \& Specht, 2012). This is further supported by the abundance of traditional games that exist in Indonesia (Cahyono, 2011). For example are game "Gasing", "tarik tambang", "yoyo", "ketapel”, etc. The traditional games have a positive impact on the child's progress. The impact can be the increase of creativity and imagination, increased interaction between players, and embedded noble values and certain moral messages (Cahyono, 2011). By looking at the urgency and the positive impact that is given, we as academics, researchers, and practitioners are required to foster existing cultural values by applying them in physics learning so that physics learning is meaningful and enjoyable.

\footnotetext{
${ }^{1}$ Corresponding e-mail: nunungfadilah56@gmail.com ${ }^{1}$, mundilarto@uny.ac.id ${ }^{2}$

1; https://orcid.org/0000-0002-2554-0447

2; https://orcid.org/0000-0003-2891-4317

Yogyakarta State University ${ }^{1}$, Yogyakarta State University ${ }^{2}$
} 


\section{Situation of the Problem}

One alternative solution is the development of learning models based on local wisdom through games conducted by Fahmi. The learning was done by utilizing the school environment (Fahmi, 2017). The advantages offered from this model are able to present real-world context in physics learning (Eick, 2012), develop the skills to discover and interpret what is learned (Popov \& Tevel, 2007), provides a fun learning variation (Kenney, Militana, \& Donohue, 2003), and many other advantages. With so many advantages offered, it should be investigated further related problems in the implementation of learning models based on local wisdom through the game in physics learning so that the benefits offered really obtained.

Based on the research that has been done by Fahmi, there are various problems related to the application of learning models based on local wisdom through games as well as the application of other games in physics learning. A common problem is the lack of attention to the appropriateness of the test instruments used (Etkina, Heuvelen, Brahmia, Brookes, Gentile, Murthy, Rosengrant, \& Warren, 2006). This is often the case in the development of a learning model in which no measures for the development of the test instruments used.

Student's cognitive skills should be measured by measuring instruments that are appropriate to the learning process (Sudjana, 2013; Mitana, Muwagga, \& Ssempala, 2019). Based on the literature review of the research conducted by Fahmi, it is found that the test instrument of cognitive skills used is not in accordance with the learning process that has been done. That is, the learning process applied based on local wisdom through the game, but the test instrument used is not based on local wisdom through the game. The suitability of the model with the test instrument used will make the physics cognitive skills can really be measured clearly and got feedback. This feedback will be used to further develop the physics cognitive skills better in learning. Therefore, a feasible test instrument of physics cognitive skills should be developed.

\section{Aim of the Study}

Based on the explanations that have been described before, we can know the various problems and solutions that exist. In order to produce a feasible test instrument, it is necessary to apply the principles of instrument development by analyzing the content validity. Since content validity is also a prerequisite for other validity, it must receive the highest priority during instrument development (Waltz, Strickland, \& Lenz, 2010). Therefore, evidence of validity must be obtained in the development of the test instrument to measure physics cognitive skills based on local wisdom.

\section{METHOD}

The methodology in this study is part of a larger study conducted through an instrument development model developed by Oriondo and Antonio (1985). The model was shown in Figure 1.

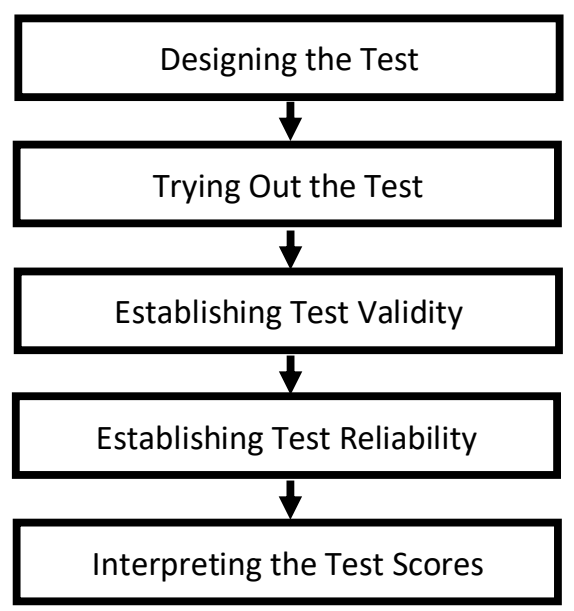

Figure 1. Research Methodology 
In accordance with the purpose of research, then in this study is limited to two stages are the design of the instrument and analysis of content validity. The purpose of first stage is to produce a test design. The test is used to measure the physics cognitive skills of 11th grade senior high school students with ages 16 to 17 years. The physics subject being tested is the equilibrium and dynamics of rotation. At this stage there are four steps. The first step is the determination of the objectives, which are related to the physics matter to be tested. The second step is selecting the appropriate item format, where the test developed is based on modern test theory (Item Response Theory, IRT). The third step is preparing the table of specifications, in which the table of test is constructed by taking into account the basic competencies and indicators physics matter. Based on the table of specification that has been made the next step is to write a test script.

After the test is complete, experts will evaluate it. This second stage is conducted to determine the value of content validity of physics test based on local wisdom. The content validity process is assessed by six experts. The selected validators are three expert lecturers from Yogyakarta State University (physics, assessment and evaluation, and physics education), while three others are from high school physics teacher in Kebumen, Indonesia. The results of the expert judgement were analyzed using Aiken's V formula to find out the content validity of the physics test.

\section{Material}

Data collection instruments used in this study were assessment questionnaires of the test instruments. The product validation questionnaire was given to the matter experts of physics, measurement and evaluation, physics education and physics teachers or practitioners. The experts assess the test instruments from aspects of substance, construction, and language. The value of the content validity is obtained based on expert judgment. For the purposes of this study, a number of $n$ experts were asked to assess the developed test instruments. In order to have sufficient control over the scoring differences, the minimum recommended number of experts is five. However, the likelihood of an agreement will decrease if the number of experts is more than ten (Lynn, 1986; Wynd, Schmidt, \& Schaefer, 2003; Yaghmale, 2003). The assessment is given qualitatively by each expert then converted to a quantitative score with a score range of 1 to 4 . The assessment questionnaire of test instruments is presented in Table 1.

Table 1. Assessment Questionnaires of the Test Instruments

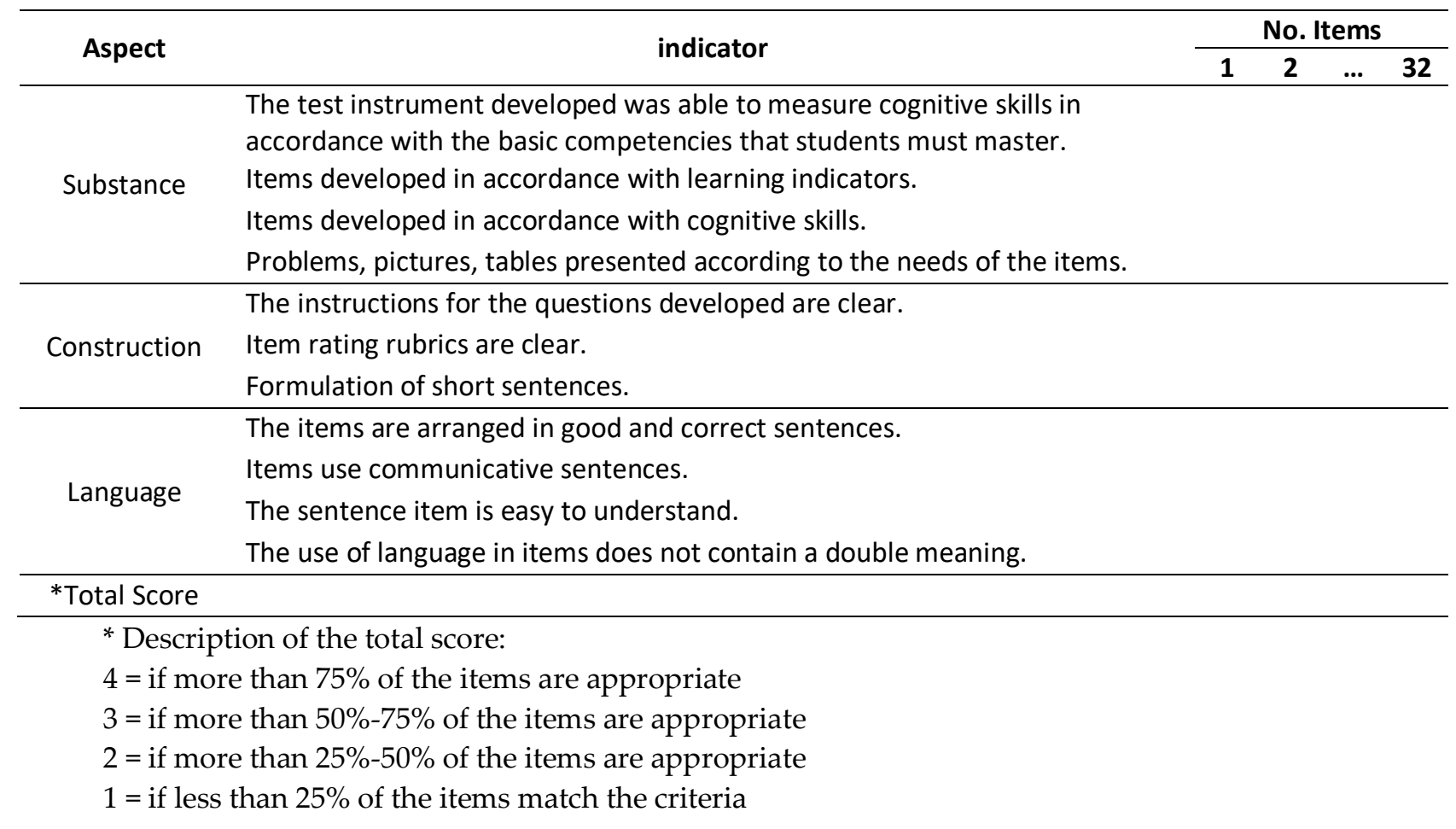

\section{Data Analyses}


Content validity analysis using formulas developed by Aiken. The formula for calculating Aiken's V index is as follows.

$$
V=\frac{\sum s}{(n(c-1))}
$$

Where $V$ is the Aiken's $\mathrm{V}$ index, $\sum s$ is the number $s$ of $n$ rater with $s=r-l_{0}, r$ is the score given by the expert, $l_{0}$ is the lowest scoring score, and $c$ is the highest scoring score. The valid criterion of an instrument is obtained by comparing Aiken's $\mathrm{V}$ index of experts with the table of validity coefficients (Aiken, 1985). For example, if the number of raters is six persons with four assessment categories, the minimum Aiken's $\mathrm{V}$ index to be obtained is 0.78 .

\section{FINDINGS}

The specification table of physics test based on local wisdom is based on the Basic Competencies used in Curriculum 2013 Indonesia. The following Table 2 presents the developed test specification.

Table 2. Test Specifications

\begin{tabular}{|c|c|c|c|}
\hline Basic Competencies & Indicators & Taxonomy Bloom & $\begin{array}{c}\text { Item } \\
\text { Number }\end{array}$ \\
\hline \multirow{32}{*}{$\begin{array}{l}\text { Applying the concept } \\
\text { of torque, moment of } \\
\text { inertia, emphasis, and } \\
\text { angular momentum } \\
\text { on rigid bodies (static } \\
\text { and dynamic) in life } \\
\text { daily. }\end{array}$} & \multirow{3}{*}{$\begin{array}{l}\text { Applying the force moment equation to solve the } \\
\text { problem of rotational dynamics }\end{array}$} & C3 & 1 \\
\hline & & $\mathrm{C} 3$ & 2 \\
\hline & & C3 & 3 \\
\hline & \multirow{3}{*}{$\begin{array}{l}\text { Applying the moment equations of inertia of an } \\
\text { object to solve the problem of rotational dynamics }\end{array}$} & C3 & 4 \\
\hline & & C3 & 5 \\
\hline & & $\mathrm{C} 5$ & 6 \\
\hline & \multirow{3}{*}{$\begin{array}{l}\text { Analyzing the moment-force relationship formulation } \\
\text { with angular acceleration to solve the problem of } \\
\text { rotational dynamics }\end{array}$} & $\mathrm{C} 4$ & 7 \\
\hline & & $\mathrm{C} 5$ & 8 \\
\hline & & $\mathrm{C} 5$ & 9 \\
\hline & \multirow{3}{*}{$\begin{array}{l}\text { Calculating the angular momentum of a moving } \\
\text { object circular }\end{array}$} & $\mathrm{C} 4$ & 10 \\
\hline & & $\mathrm{C} 4$ & 11 \\
\hline & & C3 & 12 \\
\hline & \multirow{3}{*}{$\begin{array}{l}\text { Analyzing the scale of physics related to the concept } \\
\text { of rotational dynamics in rotating objects }\end{array}$} & $\mathrm{C} 4$ & 13 \\
\hline & & C6 & 14 \\
\hline & & $\mathrm{C} 4$ & 15 \\
\hline & Applying the law of conservation of angular & C5 & 16 \\
\hline & \multirow[t]{2}{*}{ momentum in solving quantitative physics problems } & $\mathrm{C} 4$ & 17 \\
\hline & & $\mathrm{C} 5$ & 18 \\
\hline & \multirow{3}{*}{$\begin{array}{l}\text { Formulating the kinetic equation of rotation to solve } \\
\text { the problem of the motion of the object }\end{array}$} & $\mathrm{C} 4$ & 19 \\
\hline & & C6 & 20 \\
\hline & & $\mathrm{C} 4$ & 21 \\
\hline & \multirow{2}{*}{$\begin{array}{l}\text { Determining the conditions necessary to balance } \\
\text { objects. }\end{array}$} & C3 & 22 \\
\hline & & $\mathrm{C} 4$ & 23 \\
\hline & \multirow{3}{*}{$\begin{array}{l}\text { Formulating the condition of the balance of objects in } \\
\text { solving physics problems }\end{array}$} & C3 & 24 \\
\hline & & C3 & 25 \\
\hline & & C3 & 26 \\
\hline & \multirow[t]{2}{*}{ Explaining the emphasis. } & C3 & 27 \\
\hline & & C3 & 28 \\
\hline & \multirow{2}{*}{$\begin{array}{l}\text { Determining the coordinates of the gravity of an } \\
\text { object. }\end{array}$} & $\mathrm{C} 4$ & 29 \\
\hline & & C3 & 30 \\
\hline & \multirow[t]{2}{*}{ Categorizing the type of balance } & C3 & 31 \\
\hline & & C3 & 32 \\
\hline
\end{tabular}

The question form of the test is a two-tier multiple-choice questions. The form is a modification of multiple choice with two-tier answer alternative, consisting of first tier (containing five answer choices) and 
the second tier (five reasons for answer). The following is an example of a question for an indicator formulating balance requirements in solving physics problems (item to 24).

\section{Question:}

In Figures 2 and 3, a "Gasing" with a mass of $0.2 \mathrm{~kg}$ with a lower axis is between the tiles, so the "Gasing" does not shift to the right and left but the "Gasing" can still spin like the picture below.

The value of $F_{2}$ in order that the "Gasing" is not spinning is ....
A. $\frac{1}{5} F$
B. $\frac{5}{3} F$
C. $\frac{3}{5} F$
D. $\frac{5}{2} F$
E. $\frac{2}{5} F$

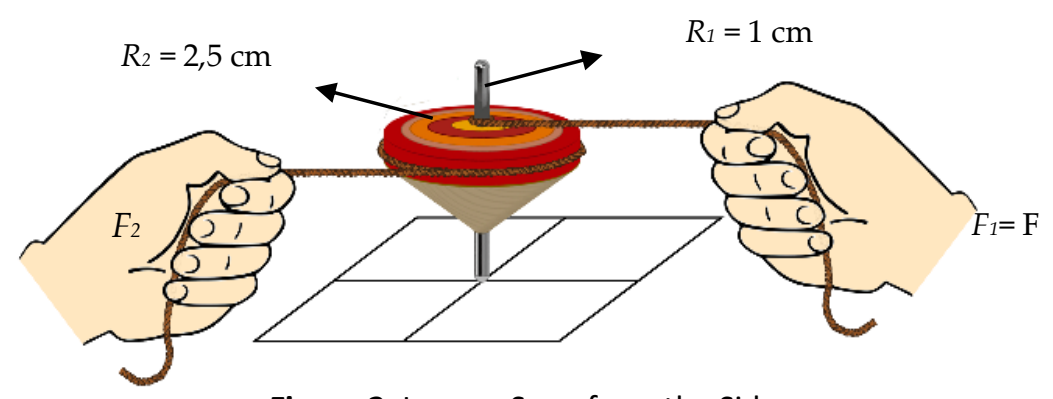

Figure 2. Images Seen from the Side

\section{Reason:}

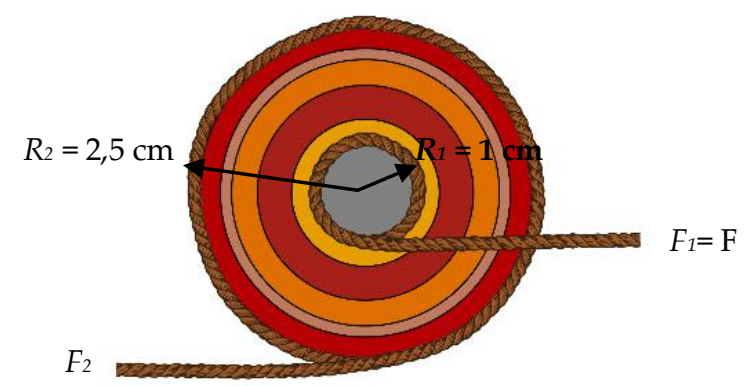
A. In accordance with Newton's 2nd Law of translation $F=m a$
B. In accordance with Newton's 2nd Law of rotation $\tau=I \alpha$
C. Qualify balance, i.e. $\sum \tau=0$
D. Qualify the law of conservation of momentum where the momentum of the angle is eternal (unchanged)
E. Qualify the law of conservation of momentum where the force is constant.

The scoring criteria used are based on the item response theory (IRT), that is the Rasch model (Istiyono, Mardapi, \& Suparno, 2014; Asysyifa, Jumadi, Wilujeng, \& Kuswanto, 2019). The criteria are divided into four categories. Score one for incorrect answer on first tier and second tier, score two for incorrect answer on first tier and correct answer on second tier, score three for correct answer on first tier and incorrect answer on second tier, and score four for correct answer on first tier and second tier.

After the test is complete, the experts will evaluate it using questionnaire presented in Table 1 . The test instruments were assessed by six experts. Expert Judgment results for the test instrument developed in the first validation steps as in Table 3. 
Table 3. Expert Judgment's Result (1 ${ }^{\text {st }}$ Validation)

\begin{tabular}{|c|c|c|c|c|c|c|c|c|}
\hline \multirow{2}{*}{ Item } & \multicolumn{6}{|c|}{ Validation Score by Experts } & \multirow{2}{*}{ CV } & \multirow{2}{*}{ Decision } \\
\hline & 1 & 2 & 3 & 4 & 5 & 6 & & \\
\hline 1 & 3 & 2 & 4 & 3 & 3 & 2 & 0.61 & invalid \\
\hline 2 & 4 & 4 & 4 & 4 & 4 & 4 & 1 & valid \\
\hline 3 & 3 & 3 & 3 & 3 & 3 & 3 & 0.67 & invalid \\
\hline 4 & 4 & 4 & 4 & 4 & 4 & 4 & 1 & valid \\
\hline 5 & 4 & 4 & 4 & 4 & 4 & 4 & 1 & valid \\
\hline 6 & 4 & 4 & 4 & 4 & 4 & 4 & 1 & valid \\
\hline 7 & 4 & 4 & 4 & 4 & 4 & 4 & 1 & valid \\
\hline 8 & 4 & 4 & 4 & 4 & 4 & 4 & 1 & valid \\
\hline 9 & 4 & 4 & 4 & 4 & 4 & 4 & 1 & valid \\
\hline 10 & 4 & 4 & 4 & 4 & 4 & 4 & 1 & valid \\
\hline 11 & 4 & 4 & 4 & 4 & 4 & 4 & 1 & valid \\
\hline 12 & 4 & 4 & 4 & 4 & 4 & 4 & 1 & valid \\
\hline 13 & 4 & 4 & 4 & 4 & 4 & 4 & 1 & valid \\
\hline 14 & 4 & 4 & 4 & 4 & 4 & 4 & 1 & valid \\
\hline 15 & 4 & 4 & 4 & 4 & 4 & 4 & 1 & valid \\
\hline 16 & 4 & 3 & 4 & 3 & 3 & 3 & 0.72 & invalid \\
\hline 17 & 4 & 4 & 4 & 4 & 4 & 4 & 1 & valid \\
\hline 18 & 2 & 2 & 4 & 3 & 3 & 3 & 0.61 & invalid \\
\hline 19 & 4 & 4 & 4 & 4 & 4 & 4 & 1 & valid \\
\hline 20 & 4 & 4 & 4 & 4 & 4 & 4 & 1 & valid \\
\hline 21 & 4 & 4 & 4 & 4 & 4 & 4 & 1 & valid \\
\hline 22 & 4 & 4 & 4 & 4 & 4 & 4 & 1 & valid \\
\hline 23 & 4 & 4 & 4 & 4 & 4 & 4 & 1 & valid \\
\hline 24 & 4 & 4 & 4 & 4 & 4 & 4 & 1 & valid \\
\hline 25 & 4 & 3 & 3 & 2 & 2 & 3 & 0.61 & invalid \\
\hline 26 & 4 & 4 & 4 & 4 & 4 & 4 & 1 & valid \\
\hline 27 & 4 & 4 & 4 & 4 & 4 & 4 & 1 & valid \\
\hline 28 & 4 & 4 & 4 & 4 & 4 & 4 & 1 & valid \\
\hline 29 & 4 & 4 & 4 & 4 & 4 & 4 & 1 & valid \\
\hline 30 & 3 & 3 & 4 & 4 & 3 & 2 & 0.72 & invalid \\
\hline 31 & 4 & 4 & 4 & 4 & 4 & 4 & 1 & valid \\
\hline 32 & 3 & 3 & 4 & 4 & 2 & 3 & 0.72 & invalid \\
\hline
\end{tabular}

Based on Table 3, there are seven items that need to be fixed. During the first validation process, there are suggestions from some experts that are used as guidance in revising invalid items. After a revision based on the first validation and expert advice, the researcher revises the test and re-validates to the expert until the valid test as presented in Table 4.

Table 4. Revision Results in Second Validation

\begin{tabular}{ccccc}
\hline \multirow{2}{*}{ Items } & \multicolumn{2}{c}{ Before Revision } & \multicolumn{2}{c}{ After Revision } \\
\cline { 2 - 5 } & CV & Decision & CV & Decision \\
\hline 1 & 0.61 & Invalid & 1 & valid \\
3 & 0.67 & Invalid & 1 & valid \\
16 & 0.72 & Invalid & 1 & valid \\
18 & 0.61 & Invalid & 1 & valid \\
25 & 0.61 & Invalid & 1 & valid \\
30 & 0.72 & Invalid & 1 & valid \\
32 & 0.72 & Invalid & 1 & valid \\
\hline
\end{tabular}

After the expert validation is carried out twice, all items have a validity coefficient of more than 0.78 . The test instrument is declared valid.

\section{DISCUSSION AND SUGGESTIONS}

The development of the physics test instrument based on local wisdom refers to an instrument development model developed by Oriondo and Antonio, shown by Figure 1. The test instrument is a test instrument based local wisdom "Gasing" to measure the physics cognitive skills of $11^{\text {th }}$ grade senior high school students. The physics subject used is the equilibrium and dynamics of rotation. The number of items developed is 32 items. In this research, the content validity process is assessed by six experts. The selected 
validators are three expert lecturers (physics, assessment and evaluation, and physics education), while three others are from high school physics teacher in Kebumen, Indonesia, who has 15 years teaching experience. The assessment questionnaires of the test instruments consist of 3 aspects: material, construction, and language aspects that are described to be 11 items. The experts examine each item on a physics test instrument in the form of two-tier multiple-choice. The validation results from six experts will be analyzed using the Aiken's V. Based on Table 3, there are 7 items that need to be fixed. According to the record of validator, item number 1 and 3 should be changed to complete sentence. Notes for items 16 and 18, should correct the terms used in the question. Note for item 25, it should fix the symbol. Note for item 30, must correct the answer choice. Note for item 32, should fix the choice of reason. After the expert judgment is carried out twice, the test instrument is declared valid because all items have a validity coefficient of more than 0.78 . This means that the two-tier multiple-choice test of physics developed has been compatible with the substance, construction, and language aspects. Validation based on Aiken's formula of content validity is not just once or twice, it can be done several times until all items are declared valid (Astuti \& Rahayu, 2012). This is consistent with the meaning of the validity of the contents as to the extent to which the elements of the instrument are truly relevant and are representations of the constants that correspond to the purpose of measurement (Wu, Kuo, \& Wang, 2017). All items have been matched with each indicator measured, so all the items can be said to be valid from the aspect of their contents validity. This limitation still requires empirical testing to find out its empirical validity. Based on the results of research and discussion it can be concluded that local wisdom around students can be used to facilitate learning physics. Not only in the learning process but can also be applied to the assessment process. All test items developed have been declared valid because all tests have a validity coefficient of more than 0.78 . Not all local wisdom can be applied to physics subjects, but requires further study. Based on the results of the application of physics tests based on local wisdom that can increase the value of meaningfulness, for further research it is necessary to develop physics tests based on local wisdom on other subject.

\section{REFERENCES}

Aiken, L. R. (1985). Three coefficients for analyzing the reliability and validty of ratings. Educational and Psychological Measurement, 45, 131-142.

Astuti, S., \& Rahayu, E. N. (2012). Pengembangan instrumen asesmen autentik berbasis literasi sains pada materi sistem ekskresi. Lembaran Ilmu Kependidikan, 2(2), 102-110.

Asysyifa, D. S., Jumadi, Wilujeng, I., \& Kuswanto, H. (2019). Analysis of students critical thinking skills using partial credit models (PCM) in physics learning. Intenational Journal of Educational Research Review, 4 (2), 245-253.

Bowker, R. \& Tearle, P. (2007). Gardening as a learning environment: A study of children's perceptions and understanding of school gardens as part of an international project. Springer Science+Business Media B.V. Learning Environ Res, 83-100.

Cahyono, N. (2011). Transformasi Permainan Anak Indonesia. http://permainan-nusantara Retrieved 05 September, 2011.

Chartock, R. K. (2010). Strategies and lessons for culturally responsive teaching: A primer for K-12 teacher. Pearson Education: Boston.

Eick, C. J. (2012). Use of the outdoor classroom and nature-study to support sciences and literacy learning: a narrative case study of a third-grade classroom. Springer, J Sci Teacher Educ, 23, 789-803.

Etkina, E., Heuvelen, A. V., Brahmia, S. W., Brookes, D. T., Gentile, M., Murthy, S., Rosengrant, D., \& Warren, A. (2006). Scientific abilities and their assessment. Physical Review Special Topics - Physics Education Research, 020103, 1-15.

Fahmi, R. (2017). Pengembangan Model Outdoor Learning melalui Game Berbasis Local Wisdom untuk Meningkatkan Kemampuan Komunikasi dan Hasil Belajar Kognitif Peserta Didik pada Materi Keseimbangan Benda Tegar. M.Pd. thesis. Pascasarjana Pendidikan Fisika. Universitas Negeri Yogyakarta. 
Guney, B. G. \& Seker, H. (2012). The use of history of science as a cultural tool to promote students' empathy with the culture of science. Educational consultancy and research center, theory \& practice, 12(1), 533539.

Istiyono, E., Mardapi, D., \& Suparno. (2014). Penerapan Partial Credit Model pada Tes Pilihan Ganda Termodifikasi Merupakan Alternative Asesmen Fisika yang Adil. Denpasar: Prosiding konferensi Ilmiah Tahunan HEPI tahun 2014.

Kenney, J. L., Militana, H. P., \& Donohue, M. H. (2003). Helping teachers to use their school's backyard as an outdoor classroom: a report on the watershed learning center program. The journal of environmental education, 35(1), 18-26.

Lynn, M. R. (1986). Determination and quantification of content validity. Nurs Res, 2-5.

Mitana, J. M. V., Muwagga, A. M., \& Ssempala, C. (2019). Assessment for successful intelligence: A paradigm shift in classroom practice. Intenational Journal of Educational Research Review, 4 (1), 106-115.

Mungmachon, R. (2012). Knowledge and local wisdom: community treasure. International Journal of Humanities and Social Science, 2(13), 174-181.

Musanna, A. (2011). Rasionalitas dan aktualitas kearifan lokal sebagai basis Pendidikan karakter. Jurnal Pendidikan dan Kebudayaan, 17(6), 588-598.

Oriondo, L. L. \& Antonio, E. M. D. (1985). Evaluating educational outcomes (Test, measurment and evaluation). Rex Printing Company: Florentino St.

Popov, O. \& Tevel, E. (2007). Developing prospective physics teachers' skills of independent experimental work using outdoors approach. Jurnal of Baltic science education, 6(1), 47-57.

Suastra, I. W. \& Yasmini, L. P. B. (2013). Model pembelajaran fisika untuk mengembangkan kreativitas berpikir dan karakter bangsa berbasis kearifan lokal Bali. Jurnal Pendidikan Indonesia, 2(2), 221-235.

Sudjana, N. (2013). Penilaian Hasil Proses Belajar Mengajar. PT. Remaja Rosdakarya: Bandung.

Verpoorten, D., Westera, W., \& Specht, M. (2012). A quest for meta-learning gains in a physics serious game. Education and Information Technologies , 19(2), 361-374.

Vlachopoulos, D. \& Makri, A. (2017). The effect of games and simulations on higher education: a systematic literature review. International Journal of Educational Technology in Higher Education, 14(22), 1-33.

Wagiran. (2011). Pengembangan model pendidikan kearifan lokal dalam mendukung visi pembangunan provinsi daerah istimewa yogyakarta 2020. Jurnal Penelitian dan Pengembangan, 3(3), 329-339.

Waltz, C. F., Strickland, O., \& Lenz, E.R. (2010). Measurement in nursing and health research. 4th ed. Springer Publishing Company: New York.

Wu, H. M., Kuo, B. C., \& Wang, S. C. (2017). Computerized Dynamic Adaptive Tests with Immediately Individualized Feedback for Primary School Mathematics Learning. Educational Technology $\mathcal{E}$ Society, 61-72.

Wynd, C. A., Schmidt, B., \& Schaefer, M. A. (2003). Two quantitative approaches for estimating content validity. West J Nurs Res, 8-18

Yaghmale, F. (2003). Content validity and its estimation. Journal of Medical Education, 5-7. 